L. Micheli $\cdot$ S. Di Stefano $\cdot$ D. Moscone $\cdot$ G. Palleschi

S. Marini $\cdot$ M. Coletta $\cdot$ R. Draisci $\cdot$ F. delli Quadri

\title{
Production of antibodies and development of highly sensitive formats of enzyme immunoassay for saxitoxin analysis
}

Received: 20 November 2001 / Revised: 14 May 2002 / Accepted: 28 May 2002 / Published online: 24 July 2002

(C) Springer-Verlag 2002

\begin{abstract}
In this paper the production of antibodies against saxitoxin (STX) is described, as is the optimization and comparison of two competitive ELISA formats (direct and indirect) for the detection of this toxin. Tests were performed in a 96-well microplate using the toxin-specific polyclonal antibodies produced in our laboratory, obtained from rabbits immunized with saxitoxin-keyhole limpet hemocyanin (STX-KLH). In indirect ELISA format saxitoxin, conjugated to bovine serum albumin (STXBSA) was coated onto the microtitre plate and incubated with standard toxin and anti-STX antibody. A goat antirabbit IgG Peroxidase conjugate was used to enable detection. In the direct ELISA format, STX standard, STX conjugate to horseradish peroxidase (STX-HRP), and enzyme substrate/chromogen solution were sequentially added to the microplate after antibody coating.

Results showed the saxitoxin detection limit to be 3 and $10 \mathrm{pg} \mathrm{mL}^{-1}$ for direct and indirect ELISA formats, respectively.

The suitability of the assay for quantification of saxitoxin in mussels was also studied. Samples were spiked with saxitoxin before and after sample treatment to study the extraction efficiency and matrix effect, respectively. After treatment, samples were analysed at 1:1000 v/v dilution in PBS to minimize the matrix effect and to detect the regulatory limit of $40-80 \mu \mathrm{g}$ saxitoxin per $100 \mathrm{~g}$ mussels as stipulated by the Food and Drug Administration. The efficiency of extraction of saxitoxin was from 72 to
\end{abstract}

\footnotetext{
L. Micheli · S. Di Stefano · D. Moscone · G. Palleschi (®) Dipartimento di Scienze e Tecnologie Chimiche, Università di Roma "Tor Vergata",

Via della Ricerca Scientifica, 00133 Rome, Italy

e-mail: Giuseppe.Palleschi@uniroma2.it

S. Marini · M. Coletta

Dipartimento di Scienze Biochimiche e Medicina Sperimentale, Università di Roma "Tor Vergata", Via di Tor Vergata n 135, 00133 Rome, Italy

R. Draisci · F. delli Quadri

Laboratorio di Medicina Veterinaria, Istituto Superiore di Sanità, Viale Regina Margherita, 00161 Rome, Italy
}

$102 \%$. These data were confirmed by liquid chromatography coupled with fluorimetric detection, the technique currently used for quantitative determination of toxins in seafood.

Keywords Enzyme immunoassay - Saxitoxin - Paralytic shellfish poisoning

\section{Introduction}

Saxitoxin is one of the most lethal non-protein toxins $\left(\mathrm{LD}_{50} 9 \mu \mathrm{g} \mathrm{kg}^{-1}\right)$ [1]; it is one of the "paralytic shellfish poisons" (PSP), produced by several marine dinoflagellates and fresh water algae. Contamination of shellfish with saxitoxin has been associated with harmful algal blooms throughout the world.

The anthropogenic enrichment of nitrogen and phosphorus in coastal waters, the increase in aquaculture, the dispersal of marine plankton by ships' ballast water, and the transfer of shellfish stocks are considered to be among the main factors involved in the increase in cases of contamination and poisoning related to saxitoxin [2].

In humans, paralytic shellfish poisoning causes dosedependent perioral numbness or tingling sensations and progressive muscular paralysis, which can result in death through respiratory arrest [3]. The maximum tolerance levels established by the European Union and the Food and Drug Administration are 40-80 $\mu \mathrm{g}$ PSP per 100-g edible portion of fresh, frozen, or tinned shellfish [4].

The Official AOAC method for these algal toxins is the "mouse bioassay" (MBA) [5]. The limitations of this procedure are the high variability of the results and the low sensitivity. It also requires a continuous supply of mice and results are affected by test conditions such as animal strain and sample extract preparations. Other methods include fluorimetry [6] and liquid chromatography [7, 8]. The latter requires expensive equipment and pre- or post-column analyte oxidation $[7,8]$. Samples must also be analysed singly, so the method is unsuitable for routine on-site testing. 
Immunochemical methods have advantages of both sensitivity and speed, and are therefore of increasing importance in food control as rapid screening tests. Because of the highly specific antigen-antibody interaction, several laboratories have attempted to develop an immunoassay for PSP [9, 10]. Although an ELISA kit [11] for saxitoxin is now on the market, free antibodies against this toxin are not commercially available, despite this toxin having been included in the list of chemical weapon compounds (Paris Convention 13/01/1993, Low 496 25/11/1995 1A07)

In this paper the production of specific antibodies against saxitoxin is described. Among several approaches tested we found that the antibodies produced in rabbits after treatment with saxitoxin conjugated to keyhole limpet hemocyanin (KLH) were useful for the toxin assay. These antibodies were used to develop both indirect and direct enzyme-linked immunosorbent assays (ELISA). Details of the production, characterization, and test procedures for the determination of saxitoxin in mussels are reported. A comparison with the commercially available ELISA test kit is also reported.

\section{Experimental}

Reagents and materials

Saxitoxin (STX), used as standard and for conjugation, was purchased from Biomol (USA). KLH (keyhole limpets hemocyanin) was bought from Calbiochem (USA). New Zealand female threeweek-old rabbits were used for the immunization. Antibody purification was conducted using Protein A Sepharose 4 Fast Flow (Amersham Pharmacia Biotech, Uppsala, Sweden). Bicinchonic acid (BCA) (BCA Protein Assay Kit; Pierce, Rockford, USA) was used to determine protein concentration. Blank control serum was obtained from rabbits not yet immunized with the toxin. Maxisorp surface, 96-well polystyrene microtitre plates were purchased from Nunc (Roskilde, Denmark). Affinity purified anti-rabbit IgG $(\mathrm{H}+\mathrm{L}$, from goat) horseradish peroxidase (HRP) conjugate, and purified mouse IgG were purchased from Vector Laboratories (Berlingame, CA, USA). Non-fat dry milk, blotting grade, came from Bio-Rad Laboratories (Hercules, CA, USA). 3,3',5,5'-tetramethylbenzidine dihydrochloride (TMB), bovine serum albumin (BSA), ABTS $\left(2,2^{\prime}\right.$ azino bis (3-ethylbenzthiazoline-6-sulfonic acid) ammonium salt 98\%) and all other reagents were from Sigma (St Louis, MO, USA). The Ridascreen saxitoxin kit was from R-Biopharm (Germany). All solvents were of LC or analytical reagent grade (Farmitalia, Carlo Erba-MI, Italy). Mussel samples were obtained from local supermarkets. The BCR reference material containing saxitoxin (BCR-543 mussel) was purchased from the Institute for Reference Materials and Measurements (IRMM, Belgium).

Apparatus

A model 550 microplate reader (Bio-Rad) was used to read the absorbance on ELISA plates at $405 \mathrm{~nm}$. A model $238 \mathrm{UV}$ cord S II, instrument from LKB (Bromma, Sweden), at $280 \mathrm{~nm}$, was used for detection of proteins during collection of the antibodies in the purification process [12].

The LC system consisted of a Perkin-Elmer (Beaconsfield, UK) 410 LC pump and an injection port (Rheodyne 7125; Cotati, CA, USA) with $20-\mu \mathrm{L}$ loop. The column used was a Supelcosil LC-18 ( $25 \mathrm{~cm} \times 4.6 \mathrm{~mm}$ id, $5 \mu \mathrm{m}$; Supelco). The fluorimetric detector was a dual-monochromator Perkin-Elmer LC 240 fluorescence detector set at 330 (excitation) and $400 \mathrm{~nm}$ (emission). The integrating recorder was a PE Nelson model 1020 from Perkin Elmer.
Procedures for preparation of Saxitoxin conjugates

Preparation of immunogen - conjugation of saxitoxin with KLH

The immunogen was prepared according to Renz and Terplan [13]. In a typical experiment KLH $(2 \mathrm{mg})$ in sodium acetate buffer $\left(0.1 \mathrm{~mol} \mathrm{~L}^{-1}, \mathrm{pH} 4.4,0.5 \mathrm{~mL}\right)$ was mixed with saxitoxin-acetate $(150 \mu \mathrm{g})$ in the presence of formaldehyde $(37 \% \mathrm{w} / \mathrm{w}, 40 \mu \mathrm{L})$. The reaction was left to proceed at room temperature for $72 \mathrm{~h}$, then at $4{ }^{\circ} \mathrm{C}$ for another $12 \mathrm{~h}$.

The reaction mixture was dialysed against acetic acid solution $1 \mathrm{mmol} \mathrm{L}{ }^{-1}$ for $6 \mathrm{~h}$, then against deionized water for $18 \mathrm{~h}$. After the dialysis the STX-KLH was precipitated with aluminium potassium sulfate $(10 \%, 800 \mu \mathrm{L})$ and $\mathrm{NaOH}\left(1 \mathrm{~mol} \mathrm{~L}^{-1}, 500 \mu \mathrm{L}\right)$ overnight at $4{ }^{\circ} \mathrm{C}$. The resulting precipitate was washed six times with cold phosphate-buffered saline (PBS), $\mathrm{pH}$ 7.2. The conjugate was prepared freshly for each immunization, because freezing can increase the hapten-carrier toxicity [14]. Animals were immunized and boosted according to the procedure reported below.

\section{Preparation of coating antigen (STX-BSA)}

The conjugation of saxitoxin to BSA involved the one-step formaldehyde method [15]. STX acetate salt $(200 \mu \mathrm{g})$ in acetic acid $\left(0.1 \mathrm{~mol} \mathrm{~L}^{-1}\right)$ was mixed with BSA $\left(2 \mathrm{mg} ; 20 \mathrm{mg} \mathrm{mL}^{-1}\right.$ in $\left.\mathrm{H}_{2} \mathrm{O}\right)$ and formaldehyde solution $(37 \%, 12 \mu \mathrm{L})$ was added. The reaction was left to proceed at room temperature for 3 days.

The reaction mixture was dialysed against PBS buffer at $4{ }^{\circ} \mathrm{C}$ for 3 days to remove any free toxin. The average final concentration of STX-BSA, calculated by use of the BCA method, was $1.2 \mathrm{mg} \mathrm{mL}^{-1}$. The conjugate solution was stored at $-20^{\circ} \mathrm{C}$.

\section{Conjugation of STX with horseradish peroxidase}

Saxitoxin was coupled to HRP by the periodate reaction $[11,16]$. HRP (4 mg) was added to sodium periodate solution $\left(0.1 \mathrm{~mol} \mathrm{~L}^{-1}\right.$, $0.2 \mathrm{~mL}$ ) and the solution was gently mixed for $20 \mathrm{~min}$ at room temperature. The mixture was dialysed against sodium acetate buffer, $\mathrm{pH} 4.4$, overnight at $4{ }^{\circ} \mathrm{C}$ and the $\mathrm{pH}$ of the final solution was adjusted with carbonate buffer $\left(0.2 \mathrm{~mol} \mathrm{~L}^{-1}, \mathrm{pH} 9.6,20 \mu \mathrm{L}\right)$.

The activated enzyme was added to saxitoxin, as the acetate salt, $(80 \mu \mathrm{g})$ in acetic acid $\left(0.1 \mathrm{~mol} \mathrm{~L}^{-1}, 250 \mu \mathrm{L}\right)$ and the $\mathrm{pH}$ was adjusted to 7.5 with sodium carbonate buffer $\left(0.5 \mathrm{~mol} \mathrm{~L}^{-1}\right.$, $\left.\mathrm{pH} 9.6\right)$. After $45 \mathrm{~min}$ at room temperature, $\mathrm{NaBH}_{4}\left(4 \mathrm{mg} \mathrm{mL}^{-1}, 0.1 \mathrm{~mL}\right)$ was added and the mixture was incubated for $15 \mathrm{~min}$ at $4{ }^{\circ} \mathrm{C}$ and finally dialysed against PBS $\left(0.15 \mathrm{~mol} \mathrm{~L}^{-1}\right)$.

The concentration of enzyme in the conjugate was determined spectrophotometrically at $403 \mathrm{~nm}\left(80 \mu \mathrm{g} \mathrm{mL}^{-1}\right.$ protein $)$ and the residual activity was also determined with ABTS by use of a spectrophotometer $\left(1.73 \mathrm{U} \mathrm{mL}^{-1}\right.$ residual activity against $5.02 \mathrm{U} \mathrm{mL}^{-1}$ of native activity).

The analysed fractions were stocked and stored at $-20^{\circ} \mathrm{C}$.

The conjugation ratios (mol toxin bound per $\mathrm{mol}^{-1} \mathrm{HRP}$ ) could not be determined, because the PSP toxins did not sufficiently absorb UV.

Antibody production

\section{Immunization procedure}

Three rabbits were immunized using saxitoxin conjugated with KLH. Animals were immunized once every 3-4 weeks for a total of 20 times using $250 \mu \mathrm{g}$ of hapten-carrier dissolved in PBS and emulsion with complete Freud's adjuvant emulsion (CFA). The second immunization ( 3 weeks later) was performed using the same amount of antigen after emulsification with incomplete Freud's adjuvant (IFA). Subsequent immunizations were performed by injecting STX-KLH, after precipitation in aluminium potassium sulfate, plus $3 \mu \mathrm{g}$ free toxin. Blood was harvested from the rabbit's ear vein 7-10 days after the last immunization. The blood was cen- 
trifuged at 3000 r.p.m. for $1 \mathrm{~h}$ at $4{ }^{\circ} \mathrm{C}$; sera were then collected, stocked, and stored at $-20^{\circ} \mathrm{C}$ until use.

\section{Antibody purification}

Antibodies were purified with $10 \mathrm{~mL}$ protein A by affinity chromatography, the whole system consisting of the chromatographic column connected to a UV detector. The column was subjected to sequential pre-washing with: phosphate buffered saline $\mathrm{pH} 7.4$ (PBS), $\mathrm{NaCl} 0.7 \%,\left(\mathrm{NH}_{4}\right)_{2} \mathrm{SO}_{4} 1 \mathrm{~mol} \mathrm{~L}-1 \mathrm{pH} 9.0, \mathrm{MgCl}_{2} 3.5 \mathrm{~mol} \mathrm{~L}^{-1}$, and $\left(\mathrm{NH}_{4}\right)_{2} \mathrm{SO}_{4}$ again. Serum diluted in $\left(\mathrm{NH}_{4}\right)_{2} \mathrm{SO}_{4}(1 \mathrm{~mL}$ serum in $\left.9 \mathrm{~mL}\left(\mathrm{NH}_{4}\right)_{2} \mathrm{SO}_{4}\right)$ was left to run overnight continuously with a flow system. Next day antibodies were eluted with $\mathrm{MgCl}_{2}$ and the protein fraction was collected. Antibodies were dialysed in deionized water overnight and their titre determined spectrophotometrically [17].

\section{Antiserum titration}

After purification the binding specificity of the antibody against saxitoxin was measured by indirect enzyme-linked immunosorbent assay (ELISA). Polyclonal antibody screening was performed by coating the microplate with STX-BSA conjugate $\left(3 \mu \mathrm{g} \mathrm{mL} \mathrm{m}^{-1}\right.$, $100 \mu \mathrm{L}$ ) in carbonate buffer, $\mathrm{pH} 9.6$, overnight at $4{ }^{\circ} \mathrm{C}$. After a washing step with PBS-T solution (PBS+0.01\% Tween 20), the blocking buffer ( $1 \%$ skimmed milk $+10 \mu \mathrm{g} \mathrm{mL} \mathrm{mL}^{-1}$ mouse-IgG in PBS) was added to the wells and left for $1 \mathrm{~h}$ at $37^{\circ} \mathrm{C}$. The wells were then washed again and different dilutions of antibody against saxitoxin in PBLI $\left(0.1 \%\right.$ skimmed milk $+1 \mu \mathrm{g} \mathrm{mL} \mathrm{m}^{-1} \mathrm{IgG}$ in PBS) were added and the wells were incubated for $2 \mathrm{~h}$ at $4{ }^{\circ} \mathrm{C}$. Plates were washed again and the secondary antibody, labelled with HRP $(1: 1500 \mathrm{v} / \mathrm{v})$ was incubated in the wells for $1 \mathrm{~h}$. After another washing step the colorimetric reaction was performed by addition of chromogen/substrate solution $(100 \mu \mathrm{L})$ to each well. After $10 \mathrm{~min}$ incubation at room temperature the enzymatic reaction was blocked with $\mathrm{HCl}\left(2 \mathrm{~mol} \mathrm{~L}^{-1}, 100 \mu \mathrm{L}\right)$ and the absorbance at $405 \mathrm{~nm}$ was read.

To obtain polyclonal antibodies with a higher affinity for saxitoxin and titre, additional rounds of immunization were performed.

Western immunoblot [18] with purified antibodies was performed to check purity.

\section{Procedure for ELISA spectrophotometric assay}

\section{Indirect competitive assay}

For this assay the antibody titration procedure was modified in the competition step only. Fixed concentration PAb $(5 \mu \mathrm{g} \mathrm{mL}-1,50 \mu \mathrm{L})$ were added to each well and incubated for $5 \mathrm{~min}$. Different concentrations of saxitoxin in PBLI $(50 \mu \mathrm{L})$ were added and the competition reaction was performed for $1 \mathrm{~h}$ at $4{ }^{\circ} \mathrm{C}$.

\section{Direct competitive assay}

PAb against saxitoxin $\left(10 \mu \mathrm{g} \mathrm{mL} \mathrm{m}^{-1}, 50 \mu \mathrm{L}\right)$ prepared in PGG-NaCl buffer [10] $\left(0.01 \mathrm{~mol} \mathrm{~L}^{-1}\right.$ piperazine-glycylglycine $\mathrm{pH} 10.0+\mathrm{NaCl}$ $150 \mathrm{mmol} \mathrm{L}^{-1}$ ) were added to a microplate and left overnight at room temperature. After immobilization, the wells were washed three times with a solution of PBS-T (PBS+0.05\% Tween 20).

A solution of $1 \%$ skimmed milk $+10 \mu \mathrm{g} \mathrm{mL}^{-1} \mathrm{IgG}$ (mouse) prepared in coating buffer was used in the blocking step $\left(1 \mathrm{~h}\right.$ at $\left.37^{\circ} \mathrm{C}\right)$.

After washing, the competition was performed as follows. Different dilutions of saxitoxin were added in triplicate to wells with a fixed $(1: 30 \mathrm{v} / \mathrm{v})$ concentration of STX-HRP in PBS. The reaction was left to proceed for $2 \mathrm{~h}$ at room temperature then the microtitre plate was rinsed with PBS-T. Finally the chromogen/substrate solution was added to the wells and the enzymatic reaction was stopped after $10 \mathrm{~min}$ at room temperature by addition of $\mathrm{H}_{2} \mathrm{SO}_{4}$ $(2 \mathrm{~mol} \mathrm{~L}-1,100 \mu \mathrm{L})$. Absorbance was read at $405 \mathrm{~nm}$.

\section{LC analysis}

Separation and chromatographic analyses were performed as reported by Lawrence et al. [7]. This analytical method was used to analyse mussel samples for comparison of results with those from with ELISA assay.

\section{Preparation of samples}

\section{Sample extraction}

Sample extraction was performed according to the AOAC method [5]. Mussels were removed from their shells, washed in water, and homogenized. Aliquots of mussel $(1 \mathrm{~g})$ were weighed in a 4-mL glass vial and $\mathrm{HCl}\left(0.1 \mathrm{~mol} \mathrm{~L}^{-1}, 1 \mathrm{~mL}\right)$ was added. After mixing the vials were kept for $5 \mathrm{~min}$ at $85^{\circ} \mathrm{C}$. After cooling to room temperature, the solutions were adjusted to $\mathrm{pH}<4$ and water was added to a final volume of $2 \mathrm{~mL}$. The mixtures were then centrifuged at $3000 \mathrm{rpm}$ for $5 \mathrm{~min}$ to remove the tissue. For the ELISA test the supernatant $(5 \mu \mathrm{L})$ was diluted to $5 \mathrm{~mL}$ with buffer and used directly in the assay.

For LC analysis, the sample was purified by a solid-phase extraction (SPE) column cleanup. An aliquot $(1 \mathrm{~mL})$ of shellfish extract was passed through a 3-mL SPE reversed-phase $\mathrm{C}_{18}$ cartridge (Supelco) previously conditioned with methanol $(6 \mathrm{~mL})$ then $\mathrm{HCl}$ $\left(0.1 \mathrm{~mol} \mathrm{~L}^{-1}, 6 \mathrm{~mL}\right)$. The effluent, and water $(2 \mathrm{~mL})$ used to elute the remaining toxin, were collected. The volume of the solution was adjusted to $4 \mathrm{~mL}$ with water and to $\mathrm{pH} 8$ before the oxidation reaction.

To perform the peroxide oxidation aqueous $\mathrm{H}_{2} \mathrm{O}_{2}(10 \%(\mathrm{v} / \mathrm{v})$, $25 \mu \mathrm{L})$ was added to $\mathrm{NaOH}\left(1 \mathrm{~mol} \mathrm{~L}^{-1}, 250 \mu \mathrm{L}\right)$ in a $0.5-\mathrm{mL}$ plastic microcentrifuge tube. Sample extract $(100 \mu \mathrm{L})$ was then added, mixed, and left to react for $2 \mathrm{~min}$ at room temperature. Concentrated acetic acid $(20 \mu \mathrm{L})$ was then mixed with the reactant solution and $20 \mu \mathrm{L}$ of this final solution were injected into LC system.

\section{Artificial contamination of mussel tissue}

Several dilutions of saxitoxin standard were added to each gram of homogenized tissue to furnish the desired concentration. For example, $0.4 \mathrm{ng} \mathrm{mL}^{-1}$ STX corresponds to $800 \mathrm{ng} \mathrm{g}^{-1}$ tissue, when a $1: 1000(\mathrm{v} / \mathrm{v})$ dilution of tissue extract is used, and also to $80 \mu \mathrm{g}$ STX/100 g of mussel tissue, which is currently the highest permitted level for commercial mussels. Contaminated homogenates were stored at $-20^{\circ} \mathrm{C}$ or used directly in the test.

\section{Calibration plots and analysis of samples}

Standard curves were obtained by use of STX standard solutions prepared in PBS $\left(3 \times 10^{-4}-3 \mathrm{ng} \mathrm{mL}^{-1}\right.$ for direct assay and $3 \times 10^{-4}$ $3 \times 10^{2} \mathrm{ng} \mathrm{mL}^{-1}$ for indirect assay) for ELISA and in $0.03 \mathrm{~mol} \mathrm{~L}^{-1}$ acetic acid $\left(0-100 \mathrm{ng} \mathrm{mL}^{-1}\right)$ for liquid chromatography.

Calibration plots (dependence of absorbance at $450 \mathrm{~nm}$ on competitor concentration) were fitted using "non-linear four-parameter logistic calibration plots" [20].

The four-parameters logistic function is:

$f_{(x)}=\left\{\frac{a-d}{1+(x / c)^{b}}\right\}+d$

in which a and $\mathrm{d}$ are the asymptotic maximum and minimum values, respectively; $\mathrm{c}$ is the value at the inflection point $\left(\mathrm{IC}_{50}\right)$, and $\mathrm{b}$ is the slope.

To enable direct comparison of some calibration plots absorbance values were converted into their corresponding test inhibition values $\left(\% \mathrm{~A} / \mathrm{A}_{0}\right)$ as follows:

$\% \frac{A}{A_{0}}=\frac{100 \times\left(A-A_{\text {sat }}\right)}{\left(A_{0}-A_{\text {sat }}\right)}$

where $\mathrm{A}$ is the absorbance value of competitors, and $\mathrm{A}_{\text {sat }}$ and $\mathrm{A}_{0}$ are the absorbance values corresponding to the saturating analyte 
and to the non-competition concentration, respectively (as evaluated by the four-parameter logistic function).

The detection limit was defined as the concentration of saxitoxin equivalent to the three times the value of the standard deviations (s) measured in the absence of saxitoxin (mean value $-3 \mathrm{~s}$ ). The midpoint value $\left(\mathrm{IC}_{50}\right)$ was evaluated as the concentration of saxitoxin at $50 \% \mathrm{~A} / \mathrm{A}_{0}$. The working range was evaluated as the toxin concentration that gives test inhibition values of $90 \%$ and $10 \%$ of $\mathrm{A} / \mathrm{A}_{0}$.

In a preliminary study, the matrix effect of blank samples on both ELISA formats was tested. Different dilutions (0, 1:10, 1:100, $1: 1000$, and 1:10,000 v/v) in PBS, pH 7.4, of blank mussel acid extracts were fortified with STX standard solutions.

To evaluate the extraction efficiency, calibration plots were constructed for blank mussel tissue spiked with STX standard solutions $\left(0.01-0.8 \mu \mathrm{g} \mathrm{g}^{-1}\right)$ before extraction. The extraction was performed as reported in the sample-extraction procedure. Each experiment was performed in triplicate and mean values were used for curve fitting.

The data obtained for each curve were plotted and fitted by use of SigmaPlot software (SPSS). Regression analysis on the linear portion of the sigmoidal curves was also performed.

Validation samples $\left(0.2,0.4,0.8 \mu \mathrm{g} \mathrm{g}^{-1}\right.$ tissue), used to evaluate the accuracy and the precision of the methods, were prepared in the same way as for the calibration plots. These concentrations were chosen because they corresponded to double $\left(0.8 \mu \mathrm{g} \mathrm{g}^{-1}\right)$, half $\left(0.2 \mu \mathrm{g} \mathrm{g}^{-1}\right)$, and the critical level $\left(0.4 \mu \mathrm{g} \mathrm{g}^{-1}\right)$ of saxitoxin stipulated by the Food and Drug Administration.

\section{Results and discussion}

\section{Antibody production}

Specific humoral response against small molecules (haptens) can usually be achieved by coupling the small compounds to high-molecular-weight protein (e.g. keyhole limpet hemocyanin, KLH). This conjugation improves the immunogenicity of the hapten by increasing the size of the antigen [12]. Because STX is a molecule with a low molecular weight, coupling of this hapten to carrier proteins is required to induce a better specific immune response.

The conjugate STX-KLH was produced (Scheme 1) and used to immunize the rabbits. Sera obtained from these rabbits were monitored with non-competitive ELISA for the antibody production. Rabbits started to elicit antibodies as early as 5-6 weeks after immunization.

During the development of experimental procedures several changes were made to the ELISA method, mainly in the coating, blocking, and antibody-incubation steps. Analysis conditions were optimized by means of a "checkerboard" titration. Antiserum production increased substantially after the first booster. Figure 1 shows that after ap-

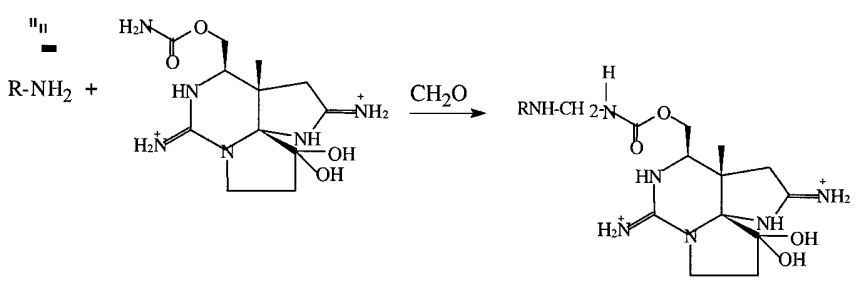

$\begin{array}{lll}\text { KLH STX } & \text { KLH - STX }\end{array}$

Scheme 1 The conjugation reaction between STX and KLH

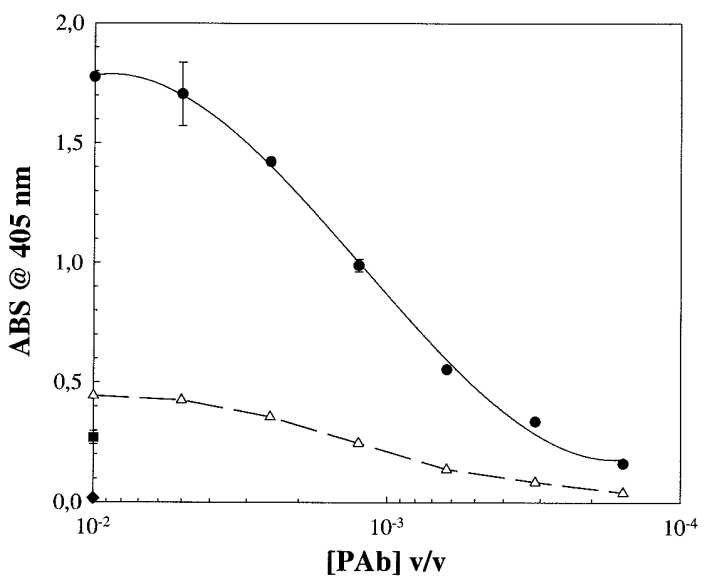

Fig. 1 Titration of antibody by indirect ELISA - antisera from rabbit immunized with STX-KLH (circles); pre-immune serum (triangles); no coating (diamonds); and no antibody (square). Antibody titre of immunoserum was $1: 100 \mathrm{v} / \mathrm{v}$

proximately 9-10 weeks antibodies were produced, as confirmed by tests performed using both specific and preimmune sera.

Polyclonal antibodies against saxitoxin were collected from those rabbits for which good titre and affinity for the antigen were achieved.

It is important to emphasize that, because of the low antigenicity of saxitoxin, several boosters were needed to obtain a good antibody titre, which was determined after purification of the antiserum on a protein A column and subsequent lyophilization of the purified product.

The titre was first determined spectrophotometrically by the Bradford assay [17]. Indirect ELISA tests were performed on this lyophilized serum and the inflection point of the curve was taken as the titre value for the antiserum. This value was $5 \mu \mathrm{g} \mathrm{mL}^{-1}$, confirming the Bradford results, and was taken as the optimum concentration of the polyclonal antibody obtained (Pab or primary antibody).

Antisera specificity and selectivity were determined by competitive ELISA in which other compounds, e.g. L-OVA (lactosylated ovalbumin) and KLH, competed with the STX-HRP conjugate for binding of antibody coated to the solid phase. KLH and L-OVA were chosen because the first was the carrier used for the conjugation and the second had the same cross-linker (bridge) of the KLH-STX conjugate, used for the immunization. These experiments were performed to detect bridge interferences usually observed for small haptens. After incubation with the STXHRP conjugate and these competitors, the conjugate bound to the antibody immobilized on the solid phase was determined by reaction with the enzyme substrate. Figure 2 shows that KLH and L-OVA did not compete with STXHRP conjugate for binding to the antibody. Our results showed that the antibodies obtained are specifically directed against the small haptens.

Studies of cross-reactivity with the STX homologs were not performed, because these products were not commercially available. 


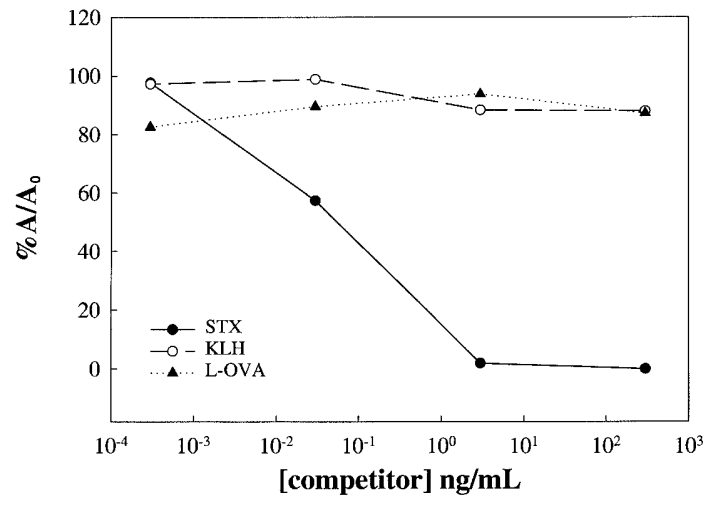

Fig. 2 Direct competitive ELISA for STX (filled circles), KLH (unfilled circles), and L-OVA (triangles). Antibody against STX $\left(10 \mu \mathrm{g} \mathrm{mL}^{-1}\right)$ was coated on the ELISA plate and STX-HRP (1:30 $\mathrm{v} / \mathrm{v}$ ) was used as competitor

\section{Optimization of ELISA procedures}

Two ELISA formats were developed to compare sensitivity, working and linear ranges, and detection limit. Optimization of ELISA conditions, e.g. temperature, buffer, and amount of antibody, was initially performed by use of standard solutions of the analyte under investigation.

For the indirect format the STX-BSA conjugate was prepared to be used as the coating antigen, to increase the response and sensitivity of the indirect assay. The use of conjugated haptens is considered necessary for non-covalent immobilization, because of the tendency of proteins to stick to the plastic surface of microwells. The involvement of protein carriers resulted in different orientations and stereochemical accessibility of hapten molecules [22].

For both systems different amounts of specific antibodies and conjugates were then tested for the development of competitive ELISA. The best conditions were found to be a coating of $3 \mu \mathrm{g} \mathrm{mL}^{-1}$ STX-BSA for the indirect format and $10 \mu \mathrm{g} \mathrm{mL}^{-1}$ of the antibody for the direct assay with 1:30 $(\mathrm{v} / \mathrm{v})$ STX-HRP (prepared during this study).

The optimized competition curves for the direct and indirect formats of the assay are shown in Figs. 3a and 3b, respectively. The working range and detection limit for saxitoxin were determined from the "non-linear four-parameter logistic calibration plots" [20].

The detection limit, defined as the concentration of toxin standard equivalent to three standard deviations at $\mathrm{A}_{0}$ (no competition), was $10 \mathrm{pg} \mathrm{mL}^{-1}$ for the indirect assay and $3 \mathrm{pg} \mathrm{mL}^{-1}$ for the direct format. The working ranges, defined as the standard toxin concentration range between $90 \%$ and $10 \%$ of the maximum signal $\left(\mathrm{A}_{0}\right)$ [23], were $3 \times 10^{-3}-3 \times 10^{-1} \mathrm{ng} \mathrm{mL}^{-1}$ for the direct assay and $3 \times 10^{-3}-$ $3 \mathrm{ng} \mathrm{mL}-1$ for the indirect format. In both tests the linear ranges were $5 \times 10^{-3}-4 \times 10^{-1} \mathrm{ng} \mathrm{mL}^{-1}$. These results indicated that the antibody had high affinity for saxitoxin. The concentrations causing $50 \%$ inhibition $\left(\mathrm{IC}_{50}\right)$ of antibody binding to the antigen (STX) were 60 and $25 \mathrm{pg} \mathrm{mL}^{-1}$, respectively, for the indirect and direct assays.
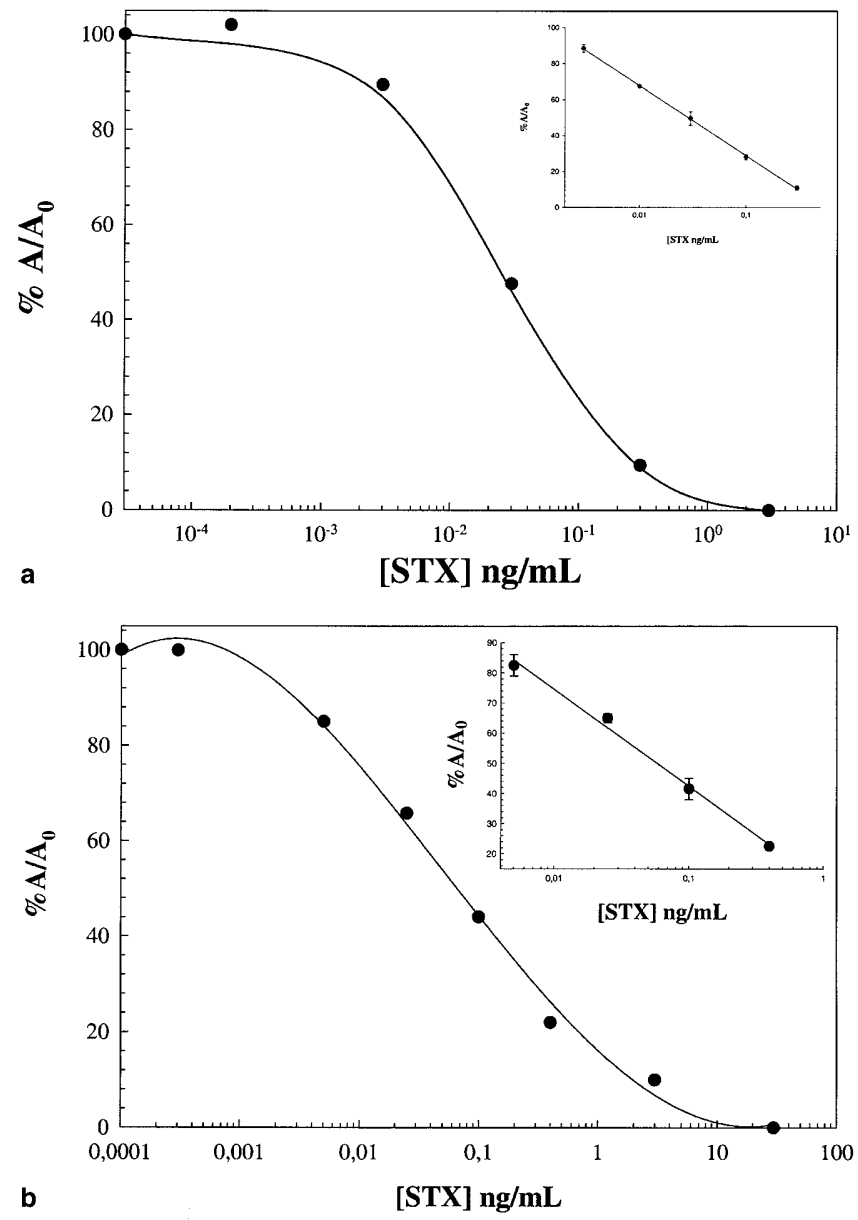

Fig. 3 (a) Direct competitive ELISA for saxitoxin. Antibody against STX $\left(10 \mu \mathrm{g} \mathrm{mL}^{-1}\right)$ was coated on the ELISA plate and STX-HRP (1:30 v/v) was used as competitor. Linear regression shows a working range of $5-400 \mathrm{pg} \mathrm{mL}^{-1}\left(\mathrm{r}^{2}=0.934\right)$ (top right insert). (b) Indirect competitive ELISA for saxitoxin. STX-BSA $\left(3 \mu \mathrm{g} \mathrm{mL}^{-1}\right)$ was coated on the ELISA plate. Linear regression shows a working range of $5-400 \mathrm{pg} \mathrm{mL}^{-1}\left(\mathrm{r}^{2}=0.990\right)$ (top right insert)

The optimized direct ELISA and the Ridascreen kit [11], a commercially available kit, were compared. The latter is based on a competitive enzyme immunoassay for quantitative analysis of STX in mussels. The microtiter plate with 48 wells is coated with antibodies directed against STX. The mean lower detection limit of the kit was approximately $10 \mathrm{pg} \mathrm{mL}^{-1}$, compared with $3 \mathrm{pg} \mathrm{mL}^{-1}$ for our direct test; this was probably because of different antibody affinity for saxitoxin. The sensitivity, defined by means of the $\mathrm{IC}_{50}$ value (parameter $\mathrm{c}$ of the logistic function), of our assay and of the commercial kit were shown to be comparable by use of the "Student t-test" $(n=6)$ [24].

\section{Stability studies}

The stability of the coating reagents was evaluated by use of microplates coated with conjugated antigen or antibody; these were then blocked and stored at $4^{\circ} \mathrm{C}$. Assays were performed periodically by use of the assessed proce- 
dures. Results showed that the plates coated with the antibodies (direct test) could be used for up to 3 weeks after the coating step whereas the antigen immobilized on the wells was stable for $24 \mathrm{~h}$ only (indirect test). Better results obtained from the direct format could, therefore, be because of higher antibody stability.

\section{Measurement of saxitoxin in mussels}

The spectrophotometric ELISA was then applied to mussels. Mussel samples were collected and the extraction procedure performed as described in the experimental section to evaluate matrix effects and extraction efficiency.

Matrix effect were characterized by using mussels in which the toxin was not present. To assess the effect of the matrix on the performance of the optimized ELISA procedures (direct and indirect formats), calibration curves were constructed by adding saxitoxin standard solutions to the pulp extract at different dilutions $(0,1: 10,1: 100,1: 1000$, $1: 10000 \mathrm{v} / \mathrm{v})$. Comparison of the results with the calibration curves obtained from use of PBS revealed the effect of the matrix was lowest when the matrix dilution was $1: 1000 \mathrm{v} / \mathrm{v}$ (data not shown). This dilution also enabled detection of the regulatory limit of $40 \mu \mathrm{g}$ saxitoxin/100 g mussels. A linear range between $5 \times 10^{-3}$ and $4 \times 10^{-1} \mathrm{ng} \mathrm{mL}^{-1}$ was obtained for both formats, although regression analysis performed in this range showed that the direct format $\left(r^{2}=0.996\right)$ gave better results than the indirect format $\left(r^{2}=0.986\right)$. For this reason, and because of the shorter

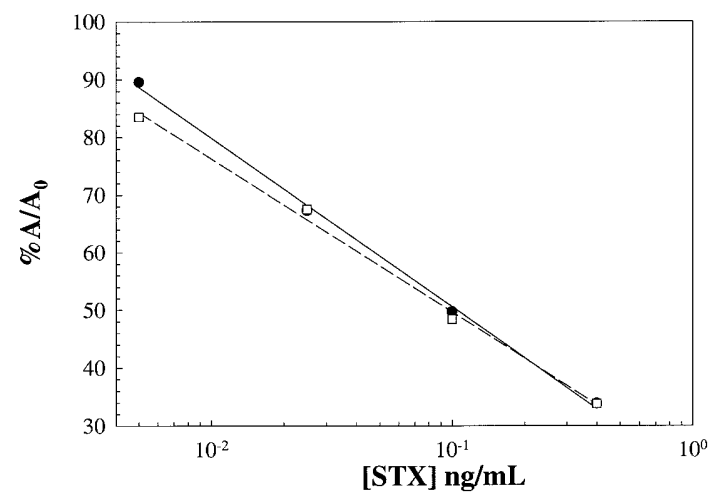

Fig. 4 Effect of sample treatment and matrix on competitive direct ELISA for saxitoxin. The calibration curves were obtained by spiking mussel with known amounts of saxitoxin before (circles) and after (squares) extraction. In both cases the extracts were diluted 1:1000 w/v and assayed time necessary for the analysis, the direct format was chosen for further experiments.

The extraction efficiency was evaluated by comparison of calibration curves (Fig.4) constructed before and after extraction of blank mussels spiked with known amounts of saxitoxin. The recovery rate for artificial contamination mussel samples ranged from 72 to $102 \%$ (the value of $72 \%$ was observed for the lowest concentration of the toxin). The repeatability and accuracy of ELISA assays were evaluated by means of six replicate analyses of tissue from mussels bought on different days and from different stores. Blank control samples fortified with saxitoxin at concentrations equal to twice $\left(0.8 \mu \mathrm{g} \mathrm{g}^{-1}\right)$, to half $\left(0.2 \mu \mathrm{g} \mathrm{g}^{-1}\right)$, and to regulatory limit $\left(0.4 \mu \mathrm{g} \mathrm{g}^{-1}\right)$ were prepared and extracted on three days for each concentration $(n=18)$.

The precision was determined by the calculation of the relative standard deviation (RSD\%) for replicate measurements and the accuracy (relative error, RE\%) was calculated by assessing the agreement between measured and nominal concentrations for the fortified samples. Results obtained were confirmed by analysis of the same extracts by use of a previously validated LC method [7]. A reference material from the IRMM was also analysed in triplicate. Results showed that the accuracy (RE\%) of the direct ELISA method was approximately 7.5\% (STX found= $0.51 \mu \mathrm{g} \mathrm{g}^{-1}$ instead of $0.48 \mu \mathrm{g} \mathrm{g}^{-1}$ as certified by the company). Values obtained for artificially contaminated mussels by use of the spectrophotometric ELISA method and the validated LC method were in good agreement (Table 1).

\section{Conclusion}

Results obtained from this study indicate that antibodies obtained from rabbits immunized with STX-KLH are suitable for the determination of STX in foods by our ELISA method.

ELISA assays were shown to be suitable screening tools for routine determination of saxitoxin in mussels. Compared with the LC method spectrophotometric direct ELISA gave similar results but with the advantages of a faster, simpler, and less expensive technique. In addition this method does not require sample purification. Stability studies showed that antibody-coated microplates could be stored for up to 3 weeks before the competition step.

Acknowledgements This work was supported by the E.C. project CT 96 FAIR 1092 and by the European Concerted Action QLK3$200-01311$ "Evaluation/Valuation of Novel Biosensors in Real Environmental and Food Samples".
Table 1 Precision (RSD) and accuracy (RE\%) for determination of saxitoxin in mussel by ELISA and LC

${ }^{\mathrm{a}} \mathrm{RE} \%($ relative error\% $)=[($ measured value-true value)/true value $] \times 100$

\begin{tabular}{|c|c|c|c|c|c|c|}
\hline \multirow{2}{*}{$\begin{array}{l}\text { STX added } \\
\left(\mu g g^{-1}\right)\end{array}$} & \multicolumn{3}{|c|}{ Direct ELISA } & \multicolumn{3}{|l|}{$\mathrm{LC}$} \\
\hline & $\begin{array}{l}\text { STX found } \\
\left(\mu \mathrm{g} \mathrm{g}^{-1}\right)\end{array}$ & RSD & $\mathrm{RE} \% \mathrm{a}$ & $\begin{array}{l}\text { STX found } \\
\left(\mu \mathrm{g} \mathrm{g}^{-1}\right)\end{array}$ & RSD & $\mathrm{RE} \%{ }^{\mathrm{a}}$ \\
\hline 0.2 & 0.17 & 6 & -15 & 0.18 & 4 & -10 \\
\hline 0.4 & 0.44 & 5 & 10 & 0.42 & 5 & 5 \\
\hline 0.8 & 0.85 & 4 & 6 & 0.84 & 5 & 5 \\
\hline
\end{tabular}




\section{References}

1. Brower DJ, Hart RJ, Matthews PA, Howden MEH (1981) Clin Toxicol 18:813-865

2. Honsell G, Nichetto P, Sidari L, Tubaro A (1995) Giornale Botanico Italiano 129:391-403

3. Uslber E, Shneider E, Terplan G, Laycock MV (1995) Food Addit Contam 12:405-413

4. Supplemento alla Gazzetta Ufficiale della Repubblica Italiana (10/9/1990), serie generale n. 21, decreto n. 256

5. Cunniff P (1999) (ed) Official methods of analysis of AOAC International, 16th edn, II(49):46B

6. Bates HA, Rapoport H (1975) J Agric Food Chem 23:237-239

7. Lawrence JF, Menard C, Cleroux C (1995) JAOAC Int 78: 514-520

8. Oshima Y (1995) J AOAC Int 78:528-532

9. Chu FS, Fan TL (1985) J Assoc Off Anal Chem 68:13-16

10. Chu FS (1996) Agric Food Chem 44:4043-4047

11. Usbler E (1991) Lett Appl Microbiol 13:275-277

12. Law B (1996) (ed) A practical guide. Taylor and Francis, London, UK, 8:157-163
13. Renz V, Terplan G (1988) Archiv fur Lebensmittelhygiene 39: $25-33$

14. Johnson H (1964) Proc Soc Exp Biol Med 117:425-430

15. Hout RS (1989) J Toxicol Environ Health 27:381-383

16. Nakame PK, Kawoi A (1974), J Histochem Cytochem 22: 1084-1091

17. Bradford MM (1976) Anal Chem 59:2642-2646

18. Towbin H, Staehelin T, Gordon J (1974) Proc Natl Acad Sci USA 76:4350

19. Smith ME, Smith LB (1949) Biol Bull 96:233-237

20. Brian Law (1996) (ed) Taylor and Francis, UK, p 160

21. Fasciglione F, Marini S, Bannister JV, Giardina B (1996) Hybridoma 15:1-9

22. Kralovec JA, Laycock MV, Richards R, Usleber E (1996) Toxin 14:1127-1140

23. Giraudi G, Rosso I, Baggiani C, Giovannoli C, Vanni A, Grassi G (1999) Anal Chim Acta 392:85-94

24. Hadjiioannou TP, Christian GD, Efstathiou CE, Nikolelis DP (1988) (ed) Pergamon Press, UK, pp 15-16 